\title{
Strengthening Indonesia's Economic Growth with Islamic and non-Islamic Macroeconomic Variable
}

\author{
Eba Ismi Alifah \\ Institut Agama Islam Negeri Salatiga, Indonesia \\ email: eba.ismi@gmail.com
}

\author{
Anton Bawono \\ Institut Agama Islam Negeri Salatiga, Indonesia \\ email: antonbawono@iainsalatiga.ac.id
}

\begin{abstract}
This research was conducted to determine the effect of taxes, Sukuk, grants, inflation, foreign debt, total financing, and the network of Islamic bank offices on Indonesia's economic growth. Research data for each variable is monthly from 2009-2018. Data analysis variables use Error Correction Model (ECM) Test and Autoregressive Conditional Heteroscedasticity (ARCH) Test with Eviews ver.10. The results showed that in the short and long term, variables taxes, Sukuk, inflation, foreign debt, total financing, and office networks of Islamic banks) affected the Indonesian economic growth. At the same time, grants have no significant effect on economic growth. For variable predictions in the next year (2019), only economic growth, grants, inflation, foreign debt, and network of Islamic bank offices can be predicted. Meanwhile, taxes, Sukuk, and total financing cannot be identified in 2019 because the variables are not significant in the ARCH analysis, so future values cannot be diagnosed. This result implies that the government and the community must continue to work together to manage state revenues used to fund productive projects to stimulate economic growth.
\end{abstract}

Keywords: Economic growth; taxes; Sukuk; inflation; foreign debt

\begin{abstract}
Abstrak: Penelitian ini dilakukan untuk mengetahui pengaruh pajak, sukuk negara, hibah, inflasi, utang luar negeri, jumlah pembiayaan dan jaringan kantor bank syariah terhadap pertumbuhan ekonomi Indonesia. Data penelitian setiap variabel berupa bulanan dari tahun 2009-2018. Uji variabel penelitian menggunakan Uji Error Correction Model (ECM) dan Uji ARCH menggunakan Eviews ver.10. Hasil penelitian menunjukkan bahwa dalam jangka pendek maupun jangka panjang, variabel pajak, sukuk negara, inflasi, utang luar negeri, jumlah pembiayaan dan jaringan kantor bank syariah berpengaruh signifikan terhadap pertumbuhan ekonomi Indonesia. Sedangkan variabel hibah tidak berpengaruh secara signifikan terhadap pertumbuhan ekonomi. Untuk prediksi variabel di tahun berikutnya (tahun 2019), hanya variabel pertumbuhan ekonomi, hibah, inflasi, utang luar negeri dan jumlah jaringan kantor bank syariah yang dapat diprediksi, sedangkan pajak, sukuk negara, dan jumlah pembiayaan tidak dapat diketahui nilai perkembangannya di tahun 2019
\end{abstract}

Economica: Jurnal Ekonomi Islam - Volume 11, Nomor 1 (2020) 
karena variabel tersebut tidak signifikan pada analisis ARCH. Sehingga tidak dapat di diagnosa dalam bentuk ARCH untuk dilakukan forecast data agar diketahui tentang nilai di masa yang akan datang. Implikasi dari temuan ini adalah diperlukan upaya yang berkesinambungan dari pemerintah dan masyarakat dalam mengelola penerimaan negara yang dimanfaatkan untuk mendanai proyek yang produktif sehingga dapat mempercepat pertumbuhan ekonomi.

Kata Kunci: Pertumbuhan ekonomi; pajak; Sukuk; inflasi; utang luar negeri 
Strengthening Indonesia's Economic Growth with...

\section{Introduction}

One indicator that Indonesians live in wealthy circumstances is the country's economic progress. Many factors influence Indonesia's economic growth, and tax is one of them. In Indonesia, taxation is one of the most important sources of government revenue (it accounts for roughly $86,5 \%$ of total revenue). Income tax (PPh), value-added tax (PPN), sales tax on luxury items (PPnBM), property tax (PBB), stamp duty, import duty/export duty, and customs are all sources of revenue (Isnanto, Istiqomah, and Suharno 2014).

Taxation has both benefits and drawbacks for the country and the general populace. Taxes are used for state funding and national development, such as employee expenses, development projects, public infrastructure, subsidizing necessary products, paying off foreign debt, and providing direction and capital to small and medium enterprises. However, taxation has a negative influence on people, such as reducing purchasing power, fraud in declaring wealth to avoid taxes, commodity price inflation, declined savings and investment in society, and reduced taxpayer motivation to individuals, groups, and enterprises. It has the potential to stifle economic growth ("Kelebihan Dan Kekurangan Pajak (Retribusi) Bagi Masyarakat" 2018).

Taxation has a favorable impact on the economy. Azka Amin, Yan Chen, and Shaoan Huang's research back it up in 2018. According to their findings, personal income tax has a good association with economic growth in Pakistan. Likewise, according to their findings, personal income tax has a positive relationship with economic growth in China (Amin, Chen, and Huang 2018).

Desislava Stoilova, in 2017 found that for the period 1996-2013, a tax structure based on selective consumption taxes, personal income taxes, and property taxes was more supportive of economic growth in the EU-28 member states (Stoilova 2017). Wahyu Nuning Sumaryani's 2015 research also found that tax income has a favorable and considerable impact on Indonesia's economic growth in the short and long run (Sumaryani 2015).

Economica: Jurnal Ekonomi Islam - Volume 11, Nomor 1 (2020) 
However, numerous studies have shown that taxes harm economic growth. According to Gareth D. Myles's research in 2000, empirical assessments of the growth effect encounter unresolved obstacles, and the empirical evidence suggests that the tax effect is negligible (Myles 2000). The impacts of tax adjustments on economic growth are investigated in Georgios Karras and Davide Furceri in 2009. The findings suggest that a rise in taxes has a negative and long-lasting effect on real GDP per capita (Karras and Furceri 2009).

According to Cornelius M. Ojong, Ogar Anthony, and Oka Felix Arikpo in 2016, there is no significant association between corporation income tax and Nigerian economic growth (Ojong et al. 2016). However, Tetsuo Ono and Yuki Uchida, in 2018, conducted research that found a shift in the tax burden from the elderly to the young and a slowing in economic growth (Ono 2018).

Numerous and diverse causes influence economic growth. Sukuk, grants, inflation, foreign debt, total financing, and the network of Islamic bank offices in Indonesia are all used in this analysis. The researcher will perform further in-depth and further research on the influence of the factors based on the preceding description. The researcher chooses that variable because the seven variables are macroeconomic variables. Macroeconomic factors have a significant impact on Indonesia's economic growth.

The APBN's primary sources of income are taxes, Sukuk, and grants; hence they play an essential role in governmental operations. If the country's state budget balance is in deficit, foreign debt can help. In addition, the state requires the inflation factor to boost people's productivity. Meanwhile, the amount of money circulating in the community is controlled by the amount of funding disbursed and the office network of Islamic banks. The seven variables are ongoing and have an impact on Indonesia's economic growth.

The study's research objectives are to identify the impact of taxes, Sukuk, grants, inflation, foreign debt, total finance, and the network of Islamic bank 
offices on Indonesia's economic growth and know future projections of variables.

This study is likely to provide a new source of information for scholars studying Indonesia's economic progress. Furthermore, this study is expected to contribute ideas and additional insight that sukuk, grants, the total Islamic bank offices, and Islamic bank financing are new Islamic economic instruments in boosting economic growth in Indonesia and non-Islamic instruments (e.g., tax, inflation and foreign debt).

\section{Literature review}

\section{Economic growth}

Economic growth increases the productivity of economic units created in a given year compared to the previous year's value, computed using GDP data at constant prices. Adopting a value based on constant prices is designed to eliminate the effect of price changes, allowing real economic growth to be quantified (Kusriyawanto 2014). In other words, economic growth is a state's ability to deliver economic products to its citizens, which can improve their wealth and welfare in the long run.

Economic growth is commonly quantified using data on Gross Domestic Product (GDP), per capita income, or the total market value of final goods and services produced by a country's economy over some time (usually one year).

\section{Tax}

Tax is an obligatory contribution to the state-owned by persons or entities that is coercive based on the law, with no direct remuneration, and used for the prosperity of the people, according to Law No. 282007 article 1 paragraph (Law of Republik Indonesia No. 28, 2007). Taxation serves as a tool for financing national development, regulating policies, balancing governmental income with the welfare of the people, and stabilizing macroeconomic crises like inflation. 


\section{Sukuk}

Based on The Accounting and Auditing Organization for Islamic Financial Institutions (AAOIFI) Sharia Standards No. 17, "Investment Sukuk are certificate of equal value representing undivided shares in ownership of tangible assets, usufruct, and services or (in the ownership of) the assets of particular projects or special investment activity. However, this is true after receipt of the value of the Sukuk, the closing of subscription, and the employment of funds received for the purpose for which the Sukuk was issued (AAOIFI 2015). Thus, Sukuk is the Indonesian government's debt to the Indonesian people or international investors in project development.

If the Sukuk matures or the project is completed, the Indonesian government must repay the sharia bonds with revenues in the form of margin/profit sharing/fees (Yahya 2015). This Sukuk must be used for projects that are free of maisyr, gharar, and usury.

\section{Grants}

According to civil law, a grant/gift is an agreement with the person who gives (Schenker), while still alive, free and irrevocable, to surrender/release an item to / for the recipient of the grant who got the handover/gift (KUHPerdata Pasal 1666 1847).

By following the memorandum of understanding (MoU) signed between the Government as the grant recipient (grantee) and the organization or donor country, the grants are expected to finance programs such as climate change, reducing emissions in urban areas, biodiversity, and forest preservation.

\section{Inflation}

Inflation, according to Friedman and Baily, is an increase in the general price level. On the other hand, according to Investopedia, inflation is defined as an increase in the general price of goods and services, resulting in a decline in purchasing power. Meanwhile, according to Shostak, inflation is caused by 
an increase in the money supply rather than an increase in the overall price of goods and services on the market (Lubis 2013).

Inflation can be helpful to producers in the short term since it raises the price level. As a result, producers will boost their output. According to Soegiharso and Gitaharie, a certain level of inflation (below the threshold number) is required to promote economic growth (Saekhu 2015).

The consumer price index (CPI), wholesale price index (IHPB), producer price index (PPI), deflator (GDP), and asset price index are all used to calculate inflation.

\section{Foreign debt}

Foreign debt is a portion of total state debt obtained from creditors outside the country. Foreign debt recipients can be government, corporate or individual. Foreign debt is obtained from private banks, governments of other countries, or international financial institutions such as the World Bank and International Monetary Fund (IMF)(Ulfa and Zulham 2017).

In the short term, foreign debt helps Indonesia overcome the deficit expenditures and considerable development spending. But in the long-term, foreign debt can cause economic problems in Indonesia such as the fall of the rupiah exchange rate (inflation). However, foreign debt is the same as development capital because it can increase investment activities to meet domestic needs.

\section{Total financing network of islamic bank offices on indonesian}

Financing is funding provided by an Islamic bank to a customer in deficit to support a planned investment conducted by individuals or institutions. In other words, financing is funding spent to support planned investments.

Financing growth is influenced by the number of sharia bank office networks in Indonesia. There are currently 15 Sharia Commercial Banks and 
20 Sharia Business Units registered with the Otoritas Jasa Keuangan (OJK) in Indonesia.

Taxes, state Sukuk, and grants obtained by the government will be repurposed for government expenditure (G), for the amount of funding, and the Sharia Bank office network will assist the community in increasing consumption (C), investment (I), and saving (S). Where GDP is positively related to (G), (C), (I), and (S). In Indonesia, GDP is one metric of economic growth. In the meantime, inflation and foreign debt reduced people's purchasing power (C) and slowed economic growth, particularly in nations with significant loans..

\section{Methods}

This study employs quantitative techniques and monthly secondary data time series from 2009 to 2018. The Central Statistics Agency (BPS) provides data on economic growth, taxes, and grants. The Ministry of Finance (Kemenkeu) provides data on state sukuk and Bank Indonesia (BI) provides data on inflation. The Foreign Debt Statistics (SULNI) provides data on foreign debt. At last, the Financial Services Authority (OJK) provides data on total financing Islamic banks and the number of sharia bank office networks. The researchers utilized Eviews ver. 10 to analyze time-series data.

\section{Result and discussion}

\section{Stationary test}

Time series data in this research must be tested stationary to determine whether the stationary data or not so that this research is avoided from a spurious regression process. The following are stationary test results on this research variable. 
Table 1. Stationary Test Results

\begin{tabular}{|c|c|c|c|c|}
\hline \multirow[t]{3}{*}{ Variable } & \multicolumn{4}{|c|}{ Unit Root Test } \\
\hline & \multicolumn{2}{|l|}{ Level } & \multicolumn{2}{|c|}{$1^{\text {st }}$ Difference } \\
\hline & ADF & Prob & ADF & Prob \\
\hline Economic Growth (Y) & -1.7129 & 0.4219 & -2.8846 & 0.0504 \\
\hline $\operatorname{Tax}(\mathrm{X} 1)$ & 0.3325 & 0.9791 & -3.2096 & 0.0221 \\
\hline Sukuk (X2) & 2.5492 & 1.0000 & -3.7096 & 0.0051 \\
\hline Grants (X3) & -1.6470 & 0.4554 & -4.5643 & 0.0003 \\
\hline Inflation (X4) & -3.2986 & 0.0171 & -7.5462 & 0.0000 \\
\hline Foreign Debt (X5) & -0.8771 & 0.7924 & -11.7827 & 0.0000 \\
\hline Total Financing (X6) & 0.5498 & 0.9877 & -3.8649 & 0.0031 \\
\hline Sharia Bank Office Network (X7) & -3.0755 & 0.0311 & -7.5253 & 0.0000 \\
\hline
\end{tabular}

Source: Results of data eviews

In Table 1, the majority of variables are not stationary at the level. So the variable must be tested again at the first difference. At this level, all variables are significant at the $5 \%$ level $(0.05)$. This means that all variables are said to be stationary at the first difference level.

\section{Cointegration test}

The Cointegration gives an early indication that a model used in this research has a long-term relationship (cointegration relation) or not. Cointegration test results are obtained by forming residuals to regress the independent variables on the dependent variable by OLS (Ordinary Least Square). Residuals must be stationary at the level to be able to say cointegration.

The regression equation model used for the cointegration test is:

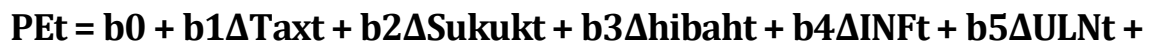

$$
\begin{aligned}
& \text { b6 } \Delta \text { Financet + b7Jarkant + et }
\end{aligned}
$$

Economica: Jurnal Ekonomi Islam - Volume 11, Nomor 1 (2020) 
Eba Ismi Alifah and Anton Bawono

After the Dickey-Fuller (DF) test, it was found that the residual was stationary at the level who seen from the t-statistic value was significant at the critical value of 5\% (Prob 0.0005). Thus, all the variables in this research can be cointegrated. The result indicates that the research model has a long-term relationship (cointegration correlation).

\section{Error correction model (ECM) test}

The regression model used in the ECM test is:

$$
\begin{gathered}
\log (\mathrm{PE}(-12))=\mathrm{C}+\log (\operatorname{tax}(-12))+\log (\operatorname{sukuk}(-12))+\log (\text { hibah }(-12))+ \\
\log (\mathrm{inf}(-12))+\log (\mathrm{ULN}(-12))+\log (\text { finance }(-12))+\log (\operatorname{jarkan}(-12))+ \\
\text { ECT }(-12)+\mathrm{e}
\end{gathered}
$$

\begin{tabular}{|c|c|c|c|c|}
\hline $\begin{array}{l}\text { Dependent Variable: L } \\
\text { Method: Least Squares } \\
\text { Date: } 08 / 20 / 19 \text { Time } \\
\text { Sample (adjusted): } 20 \\
\text { Included observations }\end{array}$ & $\begin{array}{l}\mathrm{G}(\mathrm{PE}(-12)) \\
2: 02 \\
\text { M01 2018M } \\
08 \text { after adju }\end{array}$ & ments & & \\
\hline Variable & Coefficient & Std. Error & t-Statistic & Prob. \\
\hline $\mathrm{C}$ & -4.577852 & 1.435974 & -3.187977 & 0.0019 \\
\hline $\operatorname{LOG}(\operatorname{TAX}(-12))$ & 2.052730 & 0.179652 & 11.42618 & 0.0000 \\
\hline LOG(SUKUK(-12)) & -0.095790 & 0.029324 & -3.266648 & 0.0015 \\
\hline LOG(HIBAH( $(-12))$ & 0.013998 & 0.012166 & 1.150593 & 0.2527 \\
\hline $\operatorname{LOG}(\operatorname{INF}(-12))$ & -0.101280 & 0.015578 & -6.501624 & 0.0000 \\
\hline $\operatorname{LOG}(\mathrm{ULN}(-12))$ & -0.825091 & 0.202908 & -4.066321 & 0.0001 \\
\hline LOG(FINANCE $(-12))$ & -0.858478 & 0.053547 & -16.03235 & 0.0000 \\
\hline LOG(JARKAN(-12)) & 0.579060 & 0.036480 & 15.87329 & 0.0000 \\
\hline ECT $(-12)$ & 0.173194 & 0.009756 & 17.75250 & 0.0000 \\
\hline R-squared & 0.916240 & Mean d & endent var & 1.690811 \\
\hline Adjusted R-squared & 0.909471 & S.D. $\mathrm{d}$ & endent var & 0.131764 \\
\hline S.E. of regression & 0.039645 & Akaike & fo criterion & -3.538040 \\
\hline Sum squared resid & 0.155602 & Schn & rz criterion & -3.314529 \\
\hline Log-likelihood & 200.0541 & Hannan- & uinn criter. & -3.447414 \\
\hline F-statistic & 135.3683 & Durbin & Natson stat & 0.546760 \\
\hline Prob(F-statistic) & 0.000000 & & & \\
\hline
\end{tabular}

Then the regression results are obtained as follows:

Table 2. Error Correction Model (ECM) Test Result

Source: Results of data eviews 
ECM can be said to be valid if the error correction coefficient is positive and statistically significant. Based on the error correction variable (ECT) positive sign (0.173194) and statistically significant (0.0000), it means the ECM specification model the single square cost used in this study is valid. Tax lags and Islamic bank office networks are positive, and Sukuk, inflation, foreign debt, and total financing are negative, and the variable is significant. In comparison, the grant variable has a positive but not significant.

The ECM estimation results show that this study's independent variable (variable X) affects the dependent variable (variable Y). Thus, with an R2 of 0.909 or $90.9 \%$, more than $90 \%$ of economic growth is affected by taxes, state Sukuk, grants, inflation, foreign debt, total financing, and sharia bank office networks. At the same time, the rest is influenced by variables not examined or not found in this research model. So it can be said that the types of independent variables entered in the model are reasonable.

Based on the short-term equation, using the ECM method produces the ECT coefficient. This coefficient measures the regressand response of each period that deviates from equilibrium. The balance correction coefficient on ECT in an absolute value explains how fast it takes to balance weight. For example, the ECT coefficient value is 0.173 or $17.3 \%$, which means that the difference between economic growth and the balance value is $17.3 \%$, and that value will be adjusted within one year. 


\section{Classic assumption test}

Based on testing the correlation between variables, multicollinearity is still found in this research because the R2 value of the basic model of this research was lower than the value of R2 among other research models. The correlation coefficient's absolute value ranges from zero to one. The closer it gets to one, the stronger the relation between the two variables ( $X$ and $Y$ ), and the higher the chance of multicollinearity (Iqbal 2015). The multicollinearity test has the following results.

Table 3. Correlation Test Results Between Variables (Multicollinearity Test)

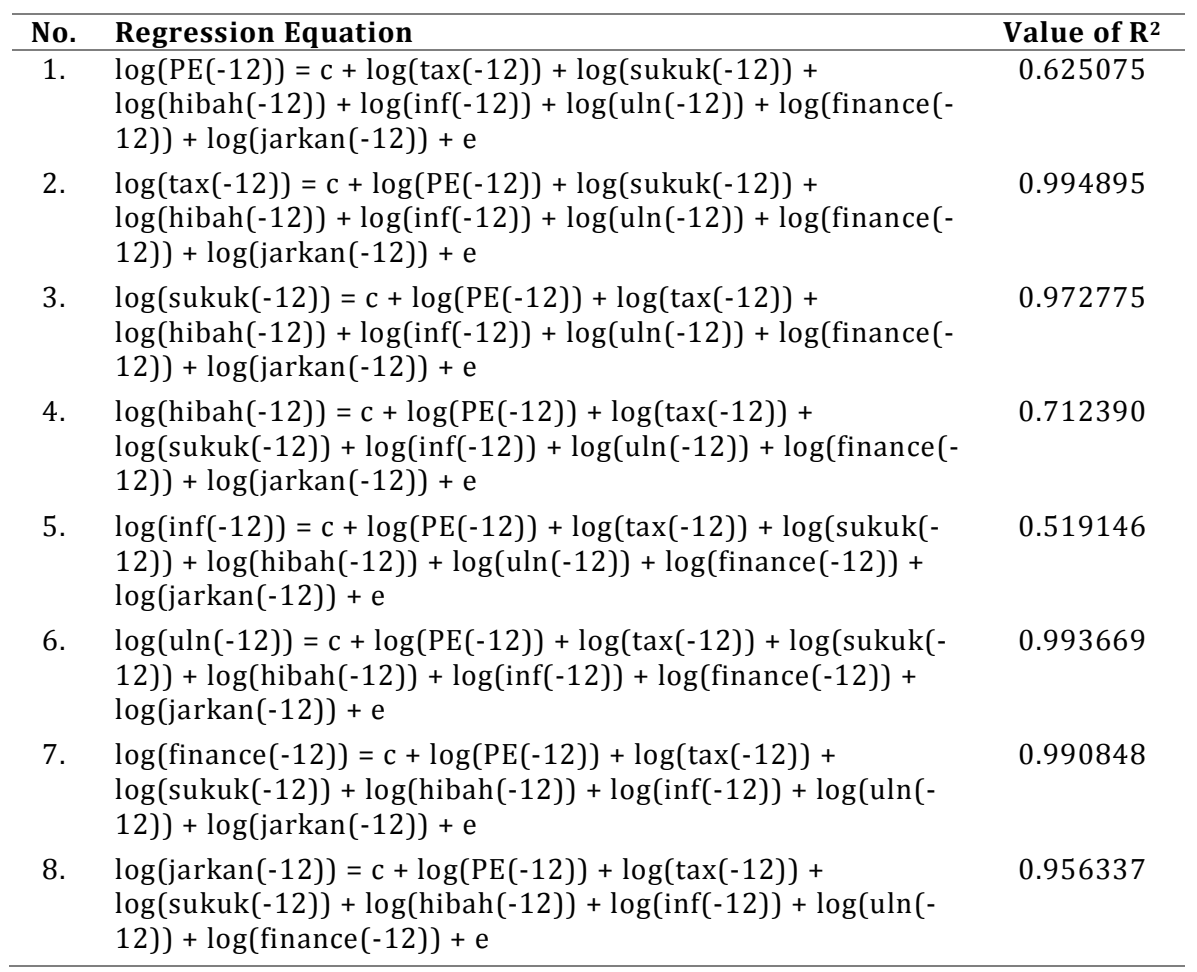

Source: Result of data Eviews 
The Durbin-Watson Test did the autocorrelation test. The DurbinWatson value in the regression test results above is 1.746756 with the Least Squares method and 2.272585 with the ARMA method. It is known that the number of autocorrelation test results for both ways is not affected by autocorrelation in this ECM research model.

For the normality test, it is known that the probability value is 0.011484 $<0.05$. Therefore, it can be concluded that the data used in the ECM research model is not normally distributed.

In the linearity test, it can be said that the model used in this study is not appropriate because of the statistical F probability value of $0.0000<0.05$. In contrast, the heteroscedasticity test is known as the value of Prob. Chi-square is 0.0038 it means smaller than $\alpha 0.05$ (5\%), so it can be concluded that in this ECM model, heteroscedasticity problems still occur. Then it must be cured using Huber-White.

Although in this study, there are still issues with the classical assumption test. However, in a book entitled "Analisis Regresi dalam Penelitian Ekonomi dan Bisnis (Dilengkapi Aplikasi SPSS \& Eviews)" by Agus Tri Basuki and Nano Prawoto, they write down the results of the classical assumption test after the ECM test is left alone, despite the fact that there were issues (Basuki and Prawoto 2016).

\section{Autoregressive conditional heteroscedasticity (ARCH) test}

\section{Economic growth}

Prediction (forecast) the value of economic growth after 2018, precisely in 2019 , is estimated to have an average value of $5.00 \%$, which means this value is lower than the average value of economic growth in 2018, which is $5.17 \%$. Based on previous research conducted by Fitri Rusdianasari, Siti Komariyah, and Moh. Adenan in 2019, the economic slowdown is caused by the Indonesian government's performance of the open economic system, such 
as trade, investment, service industries, and exchange rate performance (Rusdianasari, Komariyah, and Adenan 2019).

On the other side, population equality also contributes to slowing economic growth. The decline in economic growth figures is also a result of a decline in income and a decline in employment, resulting in a decrease in people's purchasing power (Ibrahim 2017).

\section{$\operatorname{Tax}$}

Tax revenue after 2018, precisely in 2019 , cannot be estimated. It is because the tax variable is not significant in the ARCH analysis. So tax revenue can't be diagnosed in ARCH to forecast data to be known about the value in the future. Another reason the data can't be forecasted is that data of tax have increased volatility. However, in reality, tax revenues in Indonesia continue to rise. Taxes have a contribution of more than $70-80 \%$ of total state income. The significant tax contribution makes tax the primary source of funds for the country's government and development. The government strives to maintain a constant and even more substantial tax revenue to cover state spending with fiscal and monetary policies. So that tax revenue is always controlled not to decrease (Harahap et al. 2018).

Although tax revenue still dominates state revenue, research carried out by (Rachdianti, Astuti, and Susilo 2016) (Anggraini 2018), and (Hafiz and Saryadi 2018) said that tax compliance in Indonesia is still relatively low. This can be seen from the wasn't optimal tax revenue as seen from the tax ratio (the ratio between tax revenue and the gross domestic product (GDP) of a country). The realization of tax revenue in the APBN also never reaches the target.

\section{Sukuk}

Sukuk is unknown to see the income value in 2019 because the Sukuk variable isn't significant in the ARCH analysis. So that Sukuk can't be diagnosed 
in ARCH to forecast the value in the future. The development of Sukuk in Indonesia is very rapid. Since it was published in 2008 , Sukuk has now reached more than 218 trillion rupiahs. The result shows that the increase in Sukuk is extraordinary and has an important role, especially as a patch of the state budget deficit.

The value of Indonesian Sukuk has also beaten Malaysia and the Middle East and is ranked at the top of the world's largest Sukuk issuers in the world. Currently, Indonesia holds a portion of $25.67 \%$ of the world's Sukuk. The investment-grade rating of Indonesia's global Sukuk given by Fitch Ratings said that Indonesia was at the BBB level. This level is given after evaluating many factors. The BBB rating for Indonesian Sukuk reflects Fitch's view of Indonesia's ability to fulfill its obligations(Iswara, Susyanti, and Salim 2019).

\section{Grant}

For the value of grant income after 2018, in 2019 to be exact, it is estimated to have a nominal value of approximately 463.94 billion rupiahs. It can be said that the receipt of grants fell compared to 2018, which amounted to about 1196 billion rupiahs. However, this forecast figure is close to the Ministry of Finance's prediction in the 2019 Draft State Budget, which predicts grant income of approximately 435.3 billion rupiahs.

Grants are considered to simplify and speed up the development process because they can immediately increase the domestic savings stock due to increasing the rate of growth to be achieved. Grants are believed to be able to complement the scarcity of natural resources of a developing country, help carry out the structural economic transformation, and support Third World countries in reaching the stages of takeoff development towards sustainable economic growth (Abbas and Muhtarom 2018). 


\section{Inflation}

Inflation value after 2018, precisely in 2019, is estimated to have an average value of $3.65 \%$ it means higher than the average inflation value in 2018 , which is $3.19 \%$. Therefore, based on data processing, inflation is at the level of $3.65 \%$ then this value has exceeded the target limit set by the government, which is $3.5 \%$.

The increase in inflation occurred because of the large amount of money in circulation while the goods offered on the market were small and increased production costs. In addition, failures or shocks in the country can cause price fluctuations in the domestic market and end up with inflation in the economy (Yeni, Amar, and Satrianto 2018). Factors within the country also influence inflation, but the increase in inflation can also impact contracting from abroad (Imported Inflation), namely transmission through imported goods. This inflation generally occurs in developing countries where most raw materials and equipment in their production units come from abroad (Mahendra 2016).

\section{Foreign debt}

The value of foreign debt in 2019 is estimated to have an average nominal of 300,969 million USD (three hundred thousand nine hundred sixty-nine million USD). This nominal is lower than the nominal foreign debt recorded in December 2018, namely in 377,827 million USD (three hundred seventyseven thousand eight hundred twenty-seven million USD). However, previous research said that Indonesia's foreign debt will continue to grow because Indonesia still needs many funds for development, and Indonesia still has a budget deficit (Yudiarti et al. 2018).

\section{Total financing}

The amount of total financing also can't be known as the value of its development in 2019. The unknown value is because the variable amount of financing is not significant in the ARCH analysis, and the data tends to have 
increased volatility. So, the total financing can't be diagnosed in ARCH to forecast data to be known about the value in the future. Nevertheless, the growth trend in the amount of financing in Islamic banks shows positive and increasing.

However, the growth trend of financing in Islamic banks shows a positive and increasing based on previous research that has been done by (Hawa and Rosyidi 2018) and (Fathimah 2017). They stated that the financing activities carried out by Islamic banks increased gradually and continuously from year to year. The financing activities is influenced by the high collection of funds from the public by Islamic banks.

\section{Islamic bank office networks}

The number of Islamic bank office networks in Indonesia in 2019 is estimated at 1845 office units. This means less than the total number of sharia bank office networks recorded in December 2018 of 1875 office units. The decrease of sharia bank offices probably cause by two things: the growing Islamic bank industry in Islamic commercial banks or the implementation of efficiency by companies due to the use of digital media-based banking services.

However, previous research has been done by (Anshori 2019), (Putra and Mawardi 2018), and (Zein 2018), who said that the development of sharia banking in Indonesia is good. This is supported by the development of the number of sharia banks recorded in the Indonesian Sharia Banking Statistics (OJK), showing positive growth.

\section{Conclusion}

Economic growth, taxes, state Sukuk, grants, inflation, foreign debt, total financing, and the network of Islamic bank offices are stationary at the first differentiation level. The model in this study also has a long-term relationship (cointegration correlation). Based on the ECM estimation, results show that in 
the short and long term, the variables of tax, Sukuk, inflation, foreign debt, total financing, and the network of sharia bank offices (except grants because they are insignificant) are used in this study affect economic growth. With an R2 of 0.909 or $90.9 \%$, it means that more than $90 \%$ of economic growth is affected by taxes, Sukuk, inflation, foreign debt, total financing, and the network of sharia bank offices. At the same time, the rest is influenced by other variables not examined in this research model. The ECT coefficient value is 0.173 or $17.3 \%$, which means that the difference between economic growth and the balance value is $17.3 \%$, adjusted within one year.

For variable predictions in the following year (2019), economic growth is estimated to have an average value of $5.00 \%$, it's lower than the average value of economic growth in 2018, which is $5.17 \%$. Grants in 2019 are estimated at 463.94 billion rupiahs. The receipt of grants fell compared to 2018, which amounted to approximately 1196 billion rupiahs. However, this forecast figure is close to the Ministry of Finance's prediction in the 2019 Draft State Budget, which predicts grant income of approximately 435.3 billion rupiahs. Inflation is estimated to have an average value of $3.65 \%$, which means it is higher than the average inflation value in 2018, 3.19\%. Foreign debt is estimated to have an average nominal of 300,969 million USD (three hundred thousand nine hundred sixty-nine million USD). This nominal is lower than the nominal foreign debt recorded in December 2018 (377,827 million USD). Sharia bank office networks in Indonesia are estimated to have an office network or office distribution of 1845 office units, which means less than the total number of sharia bank office networks recorded in December 2018 of 1875 office units.

The development value of taxes, state Sukuk, and total financing in 2019 is unknown because the variable was insignificant in the ARCH analysis. Taxes, state Sukuk, and total financing data are continually increasing, while in the ARCH test, one of the conditions is that the data has a high vitality. This implies that the data must reflect a changing value over time. Therefore, the variable 
can't be diagnosed in ARCH to forecast data to be known about the value in the future.

Suggestions that can be given from authors based on the study results above for further researchers by adding other macro variables that significantly impact economic growth. Besides, further research can also be carried out in the form of a combination of economic growth in several countries so that the results and conclusions of the study can be obtained better in the future.

\section{References}

AAOIFI. 2015. Accounting, Auditing and Governance Standards. Edited by AAOIFI. December 2. Manama, Bahrain: Accounting and Auditing Organization for Islamic Financial Institutions.

Abbas, Wandi, and Abid Muhtarom. 2018. “Pemanfaatan Bantuan Luar Negeri Dalam Peningkatan Ekonomi Kerakyatan Tani Kakao Di Provinsi Sulawesi Barat (Studi Program Swisscontact Periode 2013-2018)." Jurnal Manajemen 3 (1): 638. https://doi.org/10.30736/jpim.v3i1.147.

Amin, Azka, Yan Chen, and Shaoan Huang. 2018. "Personal Income Tax and Economic Growth: A Comparative Study Between China and Pakistan." Asian Journal of Economic Modelling 6 (1): 65-73. https://doi.org/10.18488/journal.8.2018.61.65.73.

Anggraini, Fibria. 2018. "Faktor -Faktor Yang Mempengaruhi Kepatuhan Pajak Wajib Pajak Orang Pribadi Dalam Rangka Penerapan Sistem Self Asessment." Balance Vocation Accounting Journal 1 (2): 53. https://doi.org/10.31000/bvaj.v1i2.476.

Anshori, Arif Rijal. 2019. "Pengaruh Jumlah Dana Pihak Ketiga (Dpk) Non Perfoming Financing (NPF) Dan Sertifikat Bank Indonesia Syari'ah (Sbis) Terhadap Penyaluran Pembiayaan Perbankan Syari'ah Di Indonesia." Jurnal MAPS (Manajemen Dan Perbankan Syariah) 2 (2): 1-21. https://doi.org/10.32483/maps.v2i2.25.

Basuki, Agus Tri, and Nano Prawoto. 2016. Analisis Regresi Dalam Penelitian Ekonomi Dan Bisnis (Dilengkapi Aplikasi SPSS \& Eviews). 
Fathimah, Vidya. 2017. “Pengaruh Perkembangan Jumlah Tabungan, Deposito Dan Bagi Hasil Terhadap Jumlah Pembiayaan Yang Diberikan Oleh Perbankan Syariah di Sumatera Utara." Jurnal Ilman 5 (1): 41-52. http://dx.doi.org/10.35126/ilman.v5i1.25.

Hafiz, Miftahudin, and Saryadi. 2018. "Pengaruh Sosialisasi Wajib Pajak Terhadap Kepatuhan Wajib Pajak Melalui Pemahaman Wajib Pajak Sebagai Variabel Intervening." Jurnal Ilmu Administrasi Bisnis 7 (3).

Harahap, Mursal, Bonar M Sinaga, Adler H Manurung, and Tubagus Nur Ahmad Maulana. 2018. "Dampak Kebijakan Dan Makroekonomi Terhadap Efektivitas Penerimaan Pajak Di Bursa Efek Indonesia." Mix: Jurnal Ilmiah Manajemen $8 \quad$ (2): 400. https://doi.org/10.22441/mix.2018.v8i2.013.

Hawa, Rusida Delfa Kendi, and Suherman Rosyidi. 2019. “Pengaruh Dpk, Imbal Hasil Sbis, Puas, Dan Tingkat Inflasi Terhadap Pembiayaan Bank Syariah Di Indonesia." Jurnal Ekonomi Syariah Teori Dan Terapan 5 (12): 1004. https://doi.org/10.20473/vol5iss201812pp1004-1019.

Ibrahim, Hilmi Rahman. 2017. "Potret Pertumbuhan Ekonomi, Kesenjangan Dan Kemiskinan Di Indonesia Dalam Tinjauan Ekonomi Politik Pembangunan." Jurnal Ilmu Dan Budaya 40 (55).

Indonesia, Presiden Republik. 2007. UU Republik Indonesia No. 28. Vol. вы12y.

Iqbal, Muhammad. 2015. "Regresi Data Panel (2) 'Tahap Analisis."' Https://Dosen.Perbanas.Id/. 2015.

Isnanto, Amin, Istiqomah, and Suharno. 2014. "Faktor-Faktor Yang Mempengaruhi Penerimaan Pajak Penghasilan Dalam APBN." Accounting Analysis Journal 3 (1): 832-36. https://doi.org/10.15294/aaj.v3i1.3907.

Iswara, Vina Indah, Jeni Susyanti, and M Agus Salim. 2019. "Pengaruh Nilai Obligasi Syariah, Rating Obligasi Syariah, Umur Obligasi Syariah Terhdap Reaksi Pasar Modal." Jurnal Ilmiah Riset Manajemen 8 (7).

Karras, Georgios, and Davide Furceri. 2009. "Taxes and Growth in Europe." South-Eastern Europe Journal of Economics, Association of Economic Universities of South and Eastern Europe and the Black Sea Region 7 (2): 181-204. https://ideas.repec.org/a/seb/journl/v7y2009i2p181204.html. 
“Kelebihan Dan Kekurangan Pajak (Retribusi) Bagi Masyarakat." 2018. Inirumahpintar.Com. 2018.

KUHPerdata Pasal 1666. 1847.

Kusriyawanto. 2014. "Pengaruh Penerimaan Dan Pengeluaran Pemerintah Daerah Terhadap Pertumbuhan Ekonomi Provinsi-Provinsi Di Indonesia Sebelum Dan Sesudah Otonomi Daerah Tahun 1994-2010."

Lubis, Ismail Fahmi. 2020. "Analisis Hubungan Antara Inflasi Dan Pertumbuhan Ekonomi: Kasus Indonesia." Quantitative Economics Journal 3 (1). https://doi.org/10.24114/qej.v3i1.17443.

Mahendra. 2016. "Analisis Pengaruh Pertumbuhan Ekonomi, Pendapatan Perkapita, Inflasi Dan Pengangguran Terhadap Jumlah Penduduk Miskin Di Provinsi Sumatera Utara." Jurnal Riset Akuntansi \& Keuangan 2 (2): 123-48. http://doi.org/10.1234/akuntansi.v2i2.177.

Myles, Gareth D. 2000. “Taxation and Economic Growth.” Fiscal Studies 21 (1): 141-68. https://doi.org/10.1111/j.1475-5890.2000.tb00583.x.

Ojong, Cornelius M, Ogar Anthony, \& Oka, and Felix Arikpo. 2016. “The Impact of Tax Revenue on Economic Growth: Evidence from Nigeria." IOSR Journal of Economics and Finance 7: 32-38. http://dx.doi.org/10.9790/5933-07113238.

Ono, Tetsuo and Yuki Uchida. 2018. "Capital Income Taxation, Economic Growth, and the Politics of Public Education." Munich Personal RePEc Archive (MPRA).

Putra, Fary Adisetya, and Dr. Imron Mawardi. 2018. "Faktor Determinan Penyebab Non-Performing Financing Pada Bank Pembiayaan Rakyat Syariah Di Indonesia Periode 2008-2015 1)."

Rachdianti, Tania, Endang Siti Astuti, and Heru Susilo. 2016. "Pengaruh Penggunaan E-Tax Terhadap Kepatuhan Wajib Pajak (Studi Pada Wajib Pajak Terdaftar Di Dinas Pendapatan Daerah Kota Malang)." Jurnal Perpajakan (JEJAK)|. Vol. 11.

Rahmadayanti, C, R F Umbara, and ... 2018. "Prediksi Value-at-Risk Dengan Efek Autoregressive Conditional Heteroskedasticity (ARCH)." EProceedings ... 5 (2): 3846-58. 
Rusdianasari, Fitri, Siti Komariyah, and Moh Adenan. 2019. "Perlambatan Pertumbuhan Dan Transisi Demografi Di Indonesia." Media Trend 14 (1): 105-19. https://doi.org/10.21107/mediatrend.v14i1.4740.

Saekhu, Saekhu. 2015. “Pengaruh Inflasi Terhadap Kinerja Pembiayaan Bank Syariah, Volume Pasar Uang Antar Bank Syariah, Dan Posisi Outstanding Sertifikat Wadiah Bank Indonesia." Economica: Jurnal Ekonomi Islam 6 (1): 103-28. https://doi.org/10.21580/economica.2015.6.1.788.

Stoilova, Desislava. 2017. "Tax Structure and Economic Growth: Evidence from the European Union." Contaduría y Administración 62 (3): 1041-57. https://doi.org/10.1016/j.cya.2017.04.006.

Sumaryani, Wahyu Nuning. 2015. "Pengaruh Penerimaan Pajak Terhadap Pertumbuhan Ekonomi di Indonesia 1984-2013.” Universitas Sebelas Maret.

Ulfa, Salawati, and T Zulham. 2017. "Analisis Utang Luar Negeri Dan Pertumbuhan Ekonomi: Kajian Faktor-Faktor Yang Mempengaruhinya." Jurnal Ilmiah Mahasiswa Ekonomi Pembangunan 2 (1): 144-52. https://doi.org/10.24815/jimekp.v2i1.2474.

Yahya, Muchlis. 2015. "Analisis Normatif Kritis Kebijakan Pemanfatan Obligasi Syariah (Sukuk) Dalam Menutup Defisit Apbn." Economica: Jurnal $\begin{array}{lllll}\text { Ekonomi } & \text { Islam } & 6 & \text { (2): }\end{array}$ https://doi.org/10.21580/economica.2015.6.2.793.

Yeni, Putri, Syamsul Amar, and Alpon Satrianto. 2019. "Pengaruh Suku Bunga, Loan to Deposit Ratio (LDR) Dan Pertumbuhan Kredit Terhadap Inflasi Di Indonesia." Jurnal Ecogen 1 (3): 557. https://doi.org/10.24036/jmpe.v1i3.5026.

Yudiarti, Tri, Emilia; Candra, Mustika Prodi, Ekonomi Pembangunan, Fak Ekonomi, Dan Bisnis, and Universitas Jambi. 2018. "Pengaruh Utang Luar Negeri, Tingkat Suku Bunga Dan Neraca Transaksi Berjalan Terhadap Nilai Tukar Rupiah Terhadap Dolar Amerika Serikat." E-Journal Perdagangan Industri Dan Moneter 6 (1): 2303-1204. https://doi.org/10.22437/pim.v6i1.4448.

Zein, Aliman Syahuri. 2018. "Analisis Perilaku Nasabah Dalam Memilih Bank Syariah Di Kabupaten Mandailing Natal." At-Tijaroh: Jurnal Ilmu Manajemen Dan Bisnis Islam 4 (2): 222. https://doi.org/10.24952/tijaroh.v4i2.1100. 